\title{
An empirical analysis of constitutional review voting in the polish constitutional tribunal, 2003-2014
}

\author{
Jarosław Kantorowicz ${ }^{1}$ Nuno Garoupa ${ }^{2,3}$
}

Published online: 24 September 2015

(C) Springer Science+Business Media New York 2015

\begin{abstract}
Different theories have been developed, mainly in the context of the United States, to explain judicial decision-making. In this respect, there is an important ongoing debate over whether judges are guided by the law or by personal ideology. The analysis of the decision-making in the Polish Constitutional Tribunal seems to support the existence of some party alignment. It is to say that judicial behavior is influenced by the ideology, either because judges' preferences coincide with the interests of a specific party or because the judges are incentivized to show their loyalty to a party. Party alignment exists but subject to institutional influences. These results are in line with previous findings for other constitutional courts in Europe.
\end{abstract}

Keywords Judicial behavior · Poland · Constitutional review

JEL Classification K0

Nuno Garoupa

nunogaroupa@law.tamu.edu

Jarosław Kantorowicz

jaroslaw.kantorowicz@edle-phd.eu

1 Rotterdam Institute of Law and Economics, Erasmus University Rotterdam, Burgemeester

Oudlaan 50, P.O. Box 1738, 3000 DR Rotterdam, The Netherlands

2 Texas A\&M University School of Law, 1515 Commerce Street, Fort Worth, TX 76102, USA

3 Católica Global Law School, Lisbon, Portugal 


\section{Introduction}

Judicial behavior in any court around the world can be conceptually explained by the same determinants even though they might vary in degree. They include individual preferences, intra-court interaction and the influence of other relevant actors, including the political branches of government and the general public. It is the exact mix of these three factors that divides academics and varies across jurisdictions.

As one of the authors has explained in a previous paper (Garoupa et al. 2011a, b), judicial preferences refer to personal attributes and attitudes in respect to cases to be adjudicated, case law more generally and possible legal policy implications. ${ }^{1}$ Intracourt interaction captures the collegiality of judicial decision-making; judges cannot impose their own preferences insulated from other judges. They have to weigh their individual preferences (their disposition towards a particular outcome) and their influence on the decisions of the court (their ability to shape the outcome in terms of public policy) (Kornhauser 1992; 2003, Cameron and Kornhauser 2010). At the same time, judges also take into account the interests of external audiences; in particular, those that react more directly to judicial decisions (see generally Garoupa and Ginsburg 2010). They might be worried about exhibiting loyalty to the appointer (given the prospect of a future career under political patronage or mere gratitude). The possible reactions of the executive and legislative branches are likely to be anticipated by the judiciary and influence their decisions; judges do not want to see their power undermined by the other branches of government. The positive or negative perception by the general public might also be of significance to individual judges and collectively to the court or the group more broadly.

Different theories have been developed, mainly in the context of the United States, to explain judicial decision-making. In this respect, there is an important ongoing debate over whether judges are guided by the law or by personal ideology. Formalists take the stance that judges simply interpret and apply the constitution and the law in a conformist view of precedents. Judges are largely guided by what the law says and abide by a strict legal authoritative interpretation. Under a completely different perspective, the attitudinal model sees judicial preferences, with special emphasis on ideology, as the main explanatory model. Finally, agency or strategy theorists recognize the importance of judicial preferences but argue that they are implemented taking into account political and institutional realities. ${ }^{2}$

These different theories of judicial behavior cannot be convincingly addressed without an adequate empirical assessment. Legal scholars and political scientists have focused much empirical attention on the U.S. Supreme Court. Empirical

\footnotetext{
${ }^{1}$ For judicial preferences, see Posner (1993, 2005, 2010, 2011). For a defence of the formalist view, criticizing the empirical studies showing the presence of political influence in judicial decision-making, see Edwards and Livermore (2009). For other views, see Robertson (1998, 2010).

${ }^{2}$ For discussion and references therein, see Epstein and Knight (1998), Segal and Spaeth (2002), and Spiller et al. (2007).
} 
debate about other higher courts is an emerging literature, with notable applications in Europe and North America, ${ }^{3}$ in Asia $^{4}$ and in Latin America. ${ }^{5}$

This paper contributes to the empirical literature on judicial behavior by looking at constitutional review in Poland. The creation and the major reforms of judicial review in Poland coincide with a transition from the socialist regime to democracy. After Former Yugoslavia, in 1985, Poland was the second socialist country to establish a constitutional court (Trybunał Konstytucyjny, hereinafter TK) with an exclusive right to review laws for their conformity with the (then socialist) Constitution (Sadurski 2002). In spite of its limited powers (e.g. the court could review the legislation passed only after its promulgation and the Court decisions were legally inconclusive), the TK managed to develop valuable case law even in its first years of existence under the then still prevailing socialist system (Garlicki 2002; Stawecki et al. 2008). Yet, more significant jurisprudence, on which TK managed to build its strong reputation, was developed shortly after the fall of the socialism regime in 1989. The TK legal doctrines were particularly crucial in filling the constitutional gaps of the early transitional period. It is of note that until 1997 Poland was operating under the old Stalinist Constitution of 1952, which was of limited relevance in the freshly-restored democratic regime. ${ }^{6}$ The importance of the TK legal doctrines was reflected in the new Constitution of 1997, which was largely grounded on the principles and rules designed by the Court at the outset of the transition (see Garlicki 2002; Stawecki et al. 2008). However, one should emphasize that the new Constitution of 1997 constitutes an important breakthrough in the history of the TK itself. Specifically, the Constitution brought many reforms with regard to the TK organization and strengthened its position vis-à-vis the legislature.

The contributions of the TK to the process of governing the political transformation of Poland and its current strong position within the Polish public institutions are unquestionable. However, as it is often raised in the debates over the TK, one point of concern is the potential ideological bias and party allegiance of the constitutional judges. In Poland, the nominations to the Court are exclusively vested

\footnotetext{
3 On Canada, see Tate and Sittiwong (1989), Alarie and Green (2008), Green and Alarie (2009), and Songer et al. (2011). On Germany, see Schneider (2005) and Vanberg (2005). On Italy, see Breton and Fraschini (2003), Fiorino et al. (2007, 2015), Padovano (2009), Pellegrina and Garoupa (2013), and Garoupa and Grembi (2015). On Portugal, see Amaral Garcia et al. (2009). On France, see Franck (2009, 2010). On Spain, see Garoupa et al. (2013). On Israel, see Shachar et al. (1997) and Eisenberg et al. (2012). On Australia, see Smyth and Narayan (2004).

4 On Japan, see Ramseyer and Rasmusen (2003), and in particular on the Japanese Supreme Court, see Ramseyer and Rasmusen (2006). On Taiwan, see Ginsburg (2003) and Garoupa et al. (2011a, b). On the Phillipines, see Escresa et al. (2012).

5 On Argentina, see Chávez (2004) and Helmke (2004) as well as Iaryczower et al. (2002, 2006). On Chile, see Hilbink (2007) and Carroll and Tiede (2011). On Brazil, see Arlota and Garoupa (2014). More generally, see Kapiszewski and Taylor (2008).

${ }^{6}$ It is important to stress that in 1992 the interim Little Constitution was promulgated in Poland. This Constitution did not repeal all of the rules of the Stalinist Constitution of 1952. It aimed, however, at reducing institutional uncertainty through amending and facilitating the main functional and organizational features of the state. The most important was to bring order and regularity to the confused relations between the parliament, the government and the President. Among the hottest issues, the interim Constitution was supposed to remove dual authority over foreign affairs and security matters as well as clarify the process for appointing the Prime Minister (see, for instance, Elster 1993).
} 
upon the Sejm, i.e. the lower chamber of the Parliament. As a partisan body, the Sejm perceives the nominations to the TK as important political decisions possibly assuring that judges elected to the Court have congruent policy preferences with the occasional parliamentary majority. This largely politicized process of appointments can potentially endanger the impartiality of the court. Judges nominated by the partisan bodies instead of being of the highest merits and subject exclusively to the law might be too easy driven by individual ideologies and party's interests in adjudicating specific cases. They might be further incentivized to cast ideological votes while hoping for future appointment to other public offices since constitutional judges in Poland do not serve for lifetime, but for a fixed term of 9 years after the 1997 changes. In addition, on many occasions, judges are obliged to adjudicate in cases where ideological differences are large and political stakes are significant. The reason for this is that a wide range of partisan bodies can initiate judicial review before the Court in an abstract form (that is, outside of a concrete case).

Not surprisingly, the conjecture of this paper is that the Polish constitutional court is politicized and ideology plays a role in judicial voting. It should be clarified that this study is empirically interested in the mere documentation of an ideological bias; our dataset does not disentangle strategic ideological voting (incentives) from sincere ideological voting (preferences). More significantly, to the authors' knowledge, this article is a first attempt of studying judicial behavior in the Polish TK. The results presented in the paper confirm the hypothesis that judges' decisions might be driven by their ideologies, thus convincingly refuting the conventional formalist account of judicial behavior prevalent in civil law academic scholarship. Those results hold particularly for judges chosen by the most ideologically polarized political camps, such as the left and extreme right parties. It is to stress, however, that the pure attitudinal model (the version that takes dispositional preferences in explaining judicial behavior as the only determinant) might not be entirely correct. Thus, also the institutional realities of the Polish TK are recognized in driving the behavior of the constitutional judges.

The paper goes as follows. An overview of the constitutional review in Poland is presented in Sect. 2. Section 3 illustrates potential sources of the ideological bias in the TK. Data and empirical strategy follows in Sect. 4. A preliminary quantitative analysis is introduced and discussed in Sect. 5. Regression analysis is discussed in Sect. 6. Finally, Sect. 7 concludes the paper.

\section{The case of Poland}

The Polish Constitution of 1997 was the result of the long-lasting political bargaining and log-rolling. Although the Constitutional Assembly (responsible for drafting the new constitution) was largely dominated by the left leaning parties, some conservative ideas were embedded in order to guarantee a more widespread political support for the constitution. ${ }^{7}$ Overall, it took almost 5 years for the

\footnotetext{
${ }^{7}$ For instance, the constitutional drafters introduced an innovative fiscal rule limiting the country's debt ratio to $60 \%$ of GDP.
} 
Assembly to accomplish the drafting of the document, which is exceptionally long as compared to the average constitutional deliberation of 16 months (Ginsburg et al. 2009). Delays in drafting the constitution resulted in loss of the constitutional momentum. Consequently, the final draft of the constitution was approved in referendum by only a slight majority of $52.7 \%$. Moreover, the voting turnout was low since it did not reach $50 \%$ of the eligible voters. ${ }^{8}$

Albeit some opposition against strengthening the institutional locus of the TK was present, the Constitution of 1997 significantly reinforced the position of the TK vis-à-vis the legislative body of the state. The establishment of the TK in 1985 under the non-democratic regime (keep in mind that socialism in Poland collapsed only in 1989) resulted in highly restrained powers for the Court as compared to its Western counterparts. Most importantly, the decisions of the court were not final. The judgments on unconformity of the law with the constitution were subject to a possible later consideration by the Sejm, which could reject the TK decisions by 2/3 majority. The new Constitution of 1997 and the Constitutional Court Act of 1997, i.e. two basic laws shaping the modern TK, banned this provision. Ultimately, after 2 years of transitory period, effectively in October 1999, the decisions of the TK started being final, conclusive in character, and not subject to further appeals. Under the currently binding procedures, whenever the Court adjudicates the unconstitutionality of a particular law, the challenged statute or its relevant articles become null and void. Unless it is formulated differently, the unconstitutional provisions cease to have binding legal effect at the moment of announcing the judgment. ${ }^{9}$ In some cases where the unconstitutionality of the law imposes a high burden on the state budget or the law annulment results in a legal uncertainty, the Court allows a temporary preservation of the statute (up to 18 months).

Before the reforms of 1997, the Court was composed of 12 judges, who were elected for a non-renewable term of 8 years. The new Constitution of 1997 increased the number of judges to 15 and lengthened their term to 9 years. With respect to the nominations and appointments of the judges, the regulations before and after the 1997 reform remained almost untouched although a major change concerned the appointment of the President and Vice-President of the Court. The candidates to the TK are put forward by a group of minimum 50 deputies sitting in

\footnotetext{
8 Although the Referendum Act of 1995 required at least $50 \%$ turnout for a referendum to have a biding effect, the Constitutional Act of 1992 instructed that the new constitution should be adopted in a referendum regardless of the turnout rate. The common belief in the early 1990s was that the turnout in the constitutional referendum would never achieve $50 \%$. Therefore, the establishment of a $50 \%$ turnout threshold put the constitutional project at high risk (see, for instance, Supreme Court Resolution from July 15, 1997).

9 Although according to the law, the unconstitutional statutes or articles cease to have any effective binding legal status, it is important to note that on many occasions the legislative bodies are obliged to further enforce specific TK judgments. It is particularly the case when the TK derogates the law and creates a legal vacuum. In years 2005-2008, approximately $70 \%(112 / 160)$ of judgments posed some enforcement obligation on the legislative bodies. However, $47 \%(52 / 112)$ of those judgments were not enforced by the relevant institutions (see Radzewicz 2010).
} 
the Sejm or the Presidium of the Sejm. ${ }^{10}$ From those candidates, the Sejm elects the judges to the TK by an absolute majority of votes with no less than half of the deputies present. As a consequence of this procedure, the majority in the Sejm can largely influence the elections of the constitutional judges, and give precedence to the candidates of their preference. It is to stress that unlike the judicial appointment mechanism in Germany, Italy, Portugal, or Spain, a de facto quota system does not exist in Poland (that is, there is no stable arrangement of allocating seats to the political parties). Therefore, at different point in time, changing political majorities are reflected in appointments to the TK.

Against this backdrop, it is important to note that there are several mechanisms formally entrenched in the law to secure judges' independence. First, judges are irremovable from office, ${ }^{11}$ protected by the immunity and entitled to a permanent salary. Second, judges to the Court must not belong to any political party or a trade union, nor hold high public offices. However, past political activism does not exclude possible candidates from being appointed to the Court. Third, as already mentioned, judges are not allowed to be re-elected for the following terms. After terminating the duties at the court, they can retain the status of a judge ${ }^{12}$ or continue their academic careers, provided that they were university professors prior to the appointment. It is to underscore that former judges of the TK are not deprived from serving other state functions after finishing the term in the TK. In those cases, however, they cannot retain the status of the judge.

The Tribunal is headed by its President and Vice-President. Until 1997, these bodies were elected by the Sejm therefore making the Court even more reliant on partisan choices. The new regulations of 1997 abolished this provision and introduced a mechanism where the President and Vice-President of the TK are appointed by the President of the Republic. However, in his decision, the President of the Republic is constrained to only two candidates who are recommended by the Court and are chosen from its members.

Yet, another important change in 1997 concerned the prerogatives of the President of the TK. First, the President lost the privilege to decide which judge would be a rapporteur of the pending case ${ }^{13}$ and was deprived of the right to determine the composition of the benches assigned to adjudicate in individual cases. It is of note that some cases, particularly those which are not excessively complicated and do not concern the ex ante preventive review mechanism, are

\footnotetext{
${ }^{10}$ The Presidium of the Sejm comprises the President and Deputy President of the Sejm. The main competence of the Presidium of the Sejm includes the setting of the Sejm's work agenda, organizing cooperation between the committees of the Sejm and coordinating their activities.

11 Removal from the office of the judge can be only a consequence of the disciplinary punishment by the TK. A judge may be subject to the disciplinary punishment for an infringement of provisions of the law, for act which is inconsistent with the dignity of his office or for unethical conduct which might undermine judge's confidence (see articles 8-10 of the Constitutional Tribunal Act of 1997).

12 Retention of a judicial status entitles the retiring judge to a "pension" irrespective of his/her age.

13 The rapporteur casts an important role in the adjudicating process since s/he is in charge of drafting the judgment together with its reasoning (see $\S 42$ of the Constitutional Court Statute of 2006).
} 
adjudicated in small benches of three or five judges. ${ }^{14}$ The existing law obliges the President of the TK to assign the new cases to the judges in alphabetical order of their surnames. The assignment of the judge rapporteur is accomplished in the same manner. The second reform referred to the fact that the President's vote was no longer decisive in situations where the number of votes for and against a particular judgment is equal. After the amendments of 1997, the law states explicitly that the decisions by the TK are made by the majority of votes and no special role for the President is defined.

As to the voting and decision-making by the TK, it is important to stress that judges who disagree with the decision of the majority of the bench are allowed to present dissenting opinions (votum separatum). ${ }^{15}$ The dissenting opinion can concern the whole judgment or part of it. Judges are also allowed to present a different opinion with respect to the reasoning of the judgment (concurring opinions). Thus, judges may agree with the final decision of the bench but they disagree about the argumentation of the majority of the bench.

In this article, the attention is exclusively given to abstract judicial review. ${ }^{16}$ In this respect, a rather broad range of actors can initiate the petition: (i) the President of the Republic, (ii) the President of the Sejm or the President of the Senate, (iii) the Prime Minister, (iv) 50 deputies or 30 senators, (iv) the First President of the Supreme Court, (v) the President of the Chief Administrative Court, (vi) the Public Prosecutor-General, (vii) the President of the Supreme Chamber of Control, (viii) the Commissioner for Citizens' Rights (Ombudsmen), (ix) the National Council of the Judiciary, (x) the constitutive bodies of local self-government, (xi) the national bodies of trade unions as well as the national authorities of employers' organizations and occupational organizations, and (xii) churches and religious organizations. While all those actors can file for ex post abstract review, it is to stress that preventive (ex ante) abstract judicial review can be requested by the President of the Republic only.

There is no doubt that the cases in which actors (i)-(iv) serve as petitioners are mostly political in nature and where the political interests are easily identifiable. It is often the case that the political opposition which failed to strike down a particular legislation in the Parliament seeks to challenge it in the Tribunal. Those cases, naturally, enjoy the largest media cover and political visibility.

\footnotetext{
14 The TK adjudicates in three types of benches, i.e. in a full bench (at least 9 judges), five-judges bench and three-judges bench. The size of the adjudicating bench depends on the nature of the case and its complexity (see article 25 of the Constitutional Court Act of 1997).

15 In 2012, $33 \%$ of the Court decisions included at least one dissenting opinion. This is, however, the record year. In previous years, the proportion of judgments with dissenting opinions is variable. It goes from $3 \%$ in 2006 to $29 \%$ in 2011 (see Trybunał 2013).

16 An abstract review of law is not the only judicial review performed in the TK. Similarly to the U.S model of judicial review, any court in Poland can initiate concrete review. This occurs in the situation where the court has doubts about the constitutionality of legal provision which serves as a basis for the judgment (see articles 31-44 of the Constitutional Court Act of 1997).
} 


\section{Ideological bias at the Polish constitutional court}

Since the approach taken in this paper is inspired by the attitudinal and strategic models, it is argued that the Polish TK judges advance their ideological goals. More precisely, given the potential arbitrariness in constitutional adjudication and interpretation (a possible variant of judicial activism), judges rely on their ideological preferences in voting one way or the other.

There are three main arguments which allow for a conjecture that the behavior of the TK judges might be explained by such ideological bias. The first (and the main attitudinal) reason concerns the appointment procedure to the court. As already pointed out, the constitutional judges are elected to the TK through a mechanism that heavily (if not entirely) relies on the political influence of the parliamentarian majorities. ${ }^{17}$ An absolute majority of votes needed to appoint the judge by the Sejm gives no incentives to the timely majorities to appoint individuals that differ significantly from their policy preferences. The following numbers should be illustrative. In years 1997-2012, 31 judges were appointed to the TK. From those, 29 judges were nominated by the groups belonging to the then governing majorities. In most cases the opposition also proposed some candidates. However, they never received the required majority. Consequently, the governing majorities, regardless of their political position, largely assume that they do not have to share decisions concerning appointments with the opposition (hence the inexistence of a quota system). As this political behavior is common practice, it became increasingly apparent that each change of political configuration of the Sejm is reflected in future appointments. In addition, given the political importance of the Court (actual extension of the legislative process), the parliamentary majorities have a clear benefit being careful in the selection of the judges they appoint. They want to minimize a mistake of appointing an individual with very different policy preferences. It is therefore safe to presume that the preferences of the political parties and those of appointed judges are strongly aligned. In other words, there might be a sincere correlation of political and judicial preferences. Some institutional safeguards such as comfortable retirement arrangements might reinforce sincere voting.

The second argument supporting the conjecture of ideological bias of the judges is based on the limited tenure at the court (recall that judges in Poland serve their duties for 9 years only). Due to the limited tenure, the judges' future career is not entirely insulated from the influence of the political parties. One could think that judges terminating their duties at the TK seek new appointments to other high level occupations in the political sphere or they hope to play an important role in

\footnotetext{
17 The political dominance is not the only weakness of the appointment process to the TK. There are several other problems. First, the short period of time given by the law to appoint the judges to the TK (30 days) reduces the transparency of the process and practically eliminates the possibility for public debate on the candidates. Second, the information about the candidates' merits given by the nominating bodies is very limited. It is often the case that the press investigation reveals some disgraceful facts about the candidates to the TK. Thirdly, the judicial and academic circles are not invited to recommend the candidates to the TK or to examine the merits of the candidates. Fourth, there is no fixed procedure for electing the judges. Judges are appointed individually but on several occasions they were elected en banc (voting on all candidates together) (see Bojarski 2010).
} 
consultancy of lawmaking in the future. At several occasions, former constitutional judges indeed continued their careers by being nominated to other public positions. For instance, after retiring from the TK, some judges were appointed as members of the Monetary Policy Council at the National Bank of Poland and the State Election Commission, as judges of the European Court of Justice and European Court of Human Rights, as members of the Legislative Council in the Prime Minister Office, as the President of the Chief Administrative Court and as Ombudsman.

At the same time, further strategic considerations could be relevant such as reputational gains with the relevant audiences, perceived personalization of case law, or enhancing academic prestige. All these factors might explain why constitutional judges are expected to take into account political determinants in strategic ways. Finally, the third argument to support the conjecture on ideological bias is the fact that political actors challenge the laws through an abstract review, thus without a direct relation to a specific concrete dispute. Unlike in the United States, the most controversial cases in the Polish Court are filed by various political actors since they are the key players in the access to abstract review. In those cases where political actors challenge legislation, the Court has limited docket control. Thus, constitutional judges in Poland have to decide on the constitutionality of specific laws precisely because political bodies want to know the Court's standpoint, rather than providing a decision in spite of what political parties might want, like in the United States. The consequence is that judges in the TK typically have to adjudicate since there are heavy ideological differences and non-negligible political interests at stake. One can expect therefore that, at least in these politicized cases, the pattern of ideological voting should prevail.

On numerous occasions, the TK decided on cases in which ideological differences and political stakes were significant. For instance, the TK was obliged

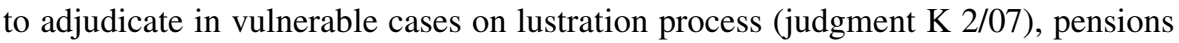
of the former secret service agents (judgment $\mathrm{K} 6 / 09$ ), relationship between the state and the church (judgment $\mathrm{K} 3 / 09$ ), financing of the catholic universities (judgment $\mathrm{K} 55 / 07$ ) and regulations of the credit unions (judgment Kp 10/09). Those cases had straightforward political implications with distinct ideological consequences. The current (in place since 2001) ideological division in Poland is, yet, more subtle than the clear left-right fragmentation typical for the old democracies. Broadly speaking, the Polish political stage can be divided into left of center (Sojusz Lewicy Demokratycznej, hereinafter SLD), center (Platforma Obywatelska, hereinafter PO) and extreme right (Prawo i Sprawiedliwość, hereinafter PiS). ${ }^{18}$ Under this setting, the largest ideological disparity should be observed between the left-wing SLD and the anti-socialist extreme right-wing party PiS. Interestingly, however, one may argue that this division does not hold in the social domain. Regarding welfare aspects, the most conservative approach is taken by PO (center).

\footnotetext{
18 In the current parliamentary setting there are three other political parties present in the Sejm, i.e. Polish People's Party (Polskie Stronnictwo Ludowe, hereinafter PSL), Palikot's Movement (Twój Ruch, hereinafter TR) and United Poland (Solidarna Polska, hereinafter SP). PSL is currently the coalition partner of the PO (centrist party). In years 1993-1997 and 2001-2003, however, this party was the coalition junior partner of the left-wing governments. TP and SP, in turn, are relatively new parties on the Polish political scene.
} 
These three arguments explain why the ideology might be crucial in determining the behavior of the Polish constitutional judges, either by sincere voting or by pondering strategic interests. Nevertheless, some limitations as to which extent ideological goals can be advanced by judges need to be recognized. We do not expect all decisions to be polarized and ideology or party alignment to explain all voting. In fact, most importantly, judges might be simply dissent averse. This can be justified by different reasons. Crucially, dissenting requires additional work (judge needs to justify the reason of a dissenting opinion). Dissenting also leads to difficulties in collegial relationships, which might have detrimental effects on the workplace (Edelman et al. 2012 and Epstein et al. 2011). Additionally, in the civil law tradition, to which Poland adheres, the emphasis is put on the consensus since dissent is perceived as harming legitimacy (Merryman and Pérez-Perdomo 2007). Excessive political and ideological division in the Court could reduce its prestige vis-à-vis other courts (in particular, the Supreme Court), and therefore diminish the influence of constitutional judges over judicial ranks, and ultimately, the legal system overall. Finally, not all cases allow the same discretion or are open to identical ideological argumentation (there is an opportunity element to be considered).

It is important to note that some literature rejects ideology as an explanation for judicial behavior. The most immediate is the traditional formalist approach by which the expectation is that judges are legalists and therefore interpret the law without influence of political variables (Edwards and Livermore 2009). With respect to the limited tenure at the court an alternative hypothesis can be derived to support the limitations of the attitudinal or strategic models. The main argument goes as follows. Politicians, contrary to what the common wisdom would suggest, are interested in having an independent judiciary for two main reasons. It is either because independent judiciary makes a legislation more durable (Landes and Posner 1975) or because independent courts can be used to shift blame for unpopular political decisions (Salzberger 1993; Voigt and Salzberger 2002). According to these arguments, after the judicial tenure, politicians should therefore reward to larger extent judicial independence rather than political alignment (Salzberger and Fenn 1999; Fiorino et al. 2015). If the political alignment is found in the Polish TK, this would mean however that this alternative argument plays rather a marginal role.

Summing-up, in this paper the following approach is taken. Constitutional judges want to advance their ideological goals, either sincerely or strategically but they are constrained by a variety of institutional factors. When those ideological goals are important, judges will sacrifice other considerations and make decisions according to the most explicit party interests. We also acknowledge alternative explanations by which ideology plays no role in judicial lawmaking.

\section{Data and empirical strategy}

This article applies regression analysis to a unique dataset collected and coded by the authors. An emphasis is given to abstract judicial review of statutes, in cases initiated by explicit political actors (i.e. the President of the Republic, 50 deputies, 
30 senators or the Presidents of Sejm and Senate) from July 2003 to October $2014 .{ }^{19}$ As already mentioned, those cases are the most politicized and particular party interests can be easily identified.

There are several reasons to constrain the cases analyzed to the chosen period. First, in the late 1990s, the TK went through major institutional changes (see Sect. 2). Most importantly, only since the end of 1999, the decisions by the TK are binding and parliamentarian supermajorities cannot reject the judgments of the Court. It is argued that timespan until 2003 is sufficient to internalize the effect of these reforms and stabilize the role of the TK under the new constitutional provisions. It is of note that no major reforms of the TK were introduced or pursued after 2003. Second, all judges adjudicating over the period 2003-2013 were chosen after the institutional reforms of 1997. Specifically, they were part of the (new designed) Court consisting of 15 judges and they all were chosen for a period of 9 years (with no possibility of reappointment). Third, at the beginning of 2000s one can observe an increase in the numbers of cases petitioned by the MPs, which most often have significant political context. For instance, while in the period 1997-2001, the Court decided an average of two cases filed by the deputies per year; in 2002-2006 it increased to six cases yearly (Trybunał 2006).

Overall the dataset includes 73 cases, 344 decisions (issues) and 3595 individual decisions (votes). Some caveats to these numbers are in order. First, the number of decisions is much larger than the number of cases since a single judgment might consist of several issues being analyzed. The reason for this is that petitioners usually challenge numerous articles of a particular legislation. Second, although the judges in the adjudicating benches vote on the whole judgment at once, it is assumed that judges cast several votes depending on the number of issues comprised in the judgment. For instance, if the judgment consists of four issues, and the decision of the bench is that all the provisions are in conformity with the constitution, the judge who does not present a dissenting opinion will be counted as casting four votes for constitutionality. ${ }^{20}$ In case s/he presents a dissenting opinion with respect to one issue, three of his/her votes are considered in favor of the constitutionality and one against it. Lastly, specifically in the Polish TK, besides declaring the simple and partial constitutionality or unconstitutionality of the provision, the adjudicating bench can decide that the provision 'is not in unconformity' with the constitution. This decision conveys that the control benchmark (constitutional provision), which was proposed by the petitioner to be the basis for judging in favor or against constitutionality of a specific article, is

\footnotetext{
19 Abstract judicial reviews of statutes are classified by the TK under two letter codes, i.e. K (ex post abstract review) and $\mathrm{Kp}$ (ex ante abstract review). Due to the fact that the availability of the documentation on the TK website is limited, it was impossible to identify petitioners in six cases, i.e. $\mathrm{K}$ $12 / 02$, K 19/02, K 34/03, K 24/04, K 38/04 and K 17/12. Consequently, those cases are not part of the dataset.

${ }^{20}$ It is important to note that the decisions in the adjudicating benches are taken by a simple majority. Judges vote secretly and if they do not agree with the final judgment, they are allowed to present the dissenting opinions. In the view of this paper, the absence of the dissenting opinion indicates that a judge, even if initially s/he voted differently than the majority, eventually s/he agrees with the decision of the adjudicating bench.
} 
considered irrelevant by the Court. In this article, for sake of empirical consistency, the view is taken as if this decision is in favor of constitutionality.

It is important to stress that among 344 decisions, unanimous decisions were an important fraction: 222 (roughly $65 \%$ ). This could serve as a first indication of dissent aversion and constraining effect of institutional realities in the TK. The 344 decisions which are studied can be divided into 66 decisions from July 2003 to October 2005 (left-wing government), 106 decisions from 2005 to November 2007 (extreme right government), 172 decisions from 2007 to 2014 (centrist government). Thus, the sample fairly represents all political cycles enabling to conclude that the econometric results are not primarily driven by a certain particular political context.

In the analyzed period, i.e. from July 2003 to October 2014, there have been in total 30 judges adjudicating in constitutional cases (one judge resigned from the post without adjudicating in any of the considered cases in our dataset). They were mostly male and, in general, they were academically oriented. Some judges had a political past, i.e. they were members of political parties or even served as MPs in the parliament. From among the 30 judges, seven were appointed by the left-wing SLD. The remaining judges were appointed by center and right-wing parties. However, it is of note that some of the parties which nominated judges in our dataset disappeared at some point before 2014 (Akcja Wyborcza Solidarność, hereinafter AWS; Unia Wolności, hereinafter UW) or lost representation in the parliament during the period we consider (Liga Polskich Rodzin, hereinafter LPR).

We employ a two-step strategy to investigate whether the TK judges are politicized. First, by means of simple contingency analysis it will be demonstrated how vote for or against constitutionality changes depending on whether a judge was appointed by the party which challenges law to the TK. Second, we exploit a more sophisticated logistic regression to verify whether a vote for or against constitutionality depends on the political affiliation of the petitioner. However, the regression analysis allows investigating also other determinants of judicial behavior in the Polish TK. Main dependent variable and all independent variables used in the regression analysis are summarized in Table 1.

The argument to be tested goes as follows. According to strict legal formalism, there should be no systematic correlation between the dependent variable of interest (vote for or against constitutionality) and political variable informing whether the body challenging the law and the judge are associated with the same political party (Request_align). In view of formalism, the constitutional disputes should be resolved in light of facts of the case and precedents with respect to the plain meaning of the constitution and intent of its drafters. Decision for or against constitutionality should not therefore depend on the fact that body challenging the law and the judge are associated with the same political party. In a formalist model, a coefficient of the Request_align should not be statistically significant. A similar conclusion emerges when we consider alternative explanations that reject ideology as a determinant as explained in the previous section.

In line with the attitudinal and the strategic models that propose ideology as the factor shaping judicial behavior, the prediction is that variable capturing ideology should be statistically significant. Regarding the variable Request_align, it is 
Table 1 Variables used in regression analysis and their descriptive statistics

\begin{tabular}{|c|c|c|c|c|c|c|}
\hline Variables & Description & $\mathrm{N}$ & Mean & $\begin{array}{l}\text { Standard } \\
\text { deviation }\end{array}$ & Min & $\operatorname{Max}$ \\
\hline Constitutionality & $\begin{array}{l}1 \text { If decision for constitutionality, } \\
0 \text { otherwise }\end{array}$ & 3595 & 0.565 & 0.496 & 0 & 1 \\
\hline Request_align & $\begin{array}{l}1 \text { If the party of the judge } \\
\text { requested the judicial review, } 0 \\
\text { otherwise }\end{array}$ & 3595 & 0.276 & 0.447 & 0 & 1 \\
\hline Government_align & $\begin{array}{l}1 \text { If the party of the judge is in the } \\
\text { government, } 0 \text { otherwise }\end{array}$ & 3595 & 0.329 & 0.470 & 0 & 1 \\
\hline Gender & $\begin{array}{l}1 \text { If the judge is female, } 0 \\
\text { otherwise }\end{array}$ & 3595 & 0.231 & 0.422 & 0 & 1 \\
\hline Professor & $\begin{array}{l}1 \text { If the judge pursued an } \\
\text { academic career, } 0 \text { otherwise }\end{array}$ & 3595 & 0.775 & 0.418 & 0 & 1 \\
\hline Political involvement & $\begin{array}{l}1 \text { If the judge was politically } \\
\text { involved in the past, } 0 \\
\text { otherwise }\end{array}$ & 3595 & 0.403 & 0.491 & 0 & 1 \\
\hline $\mathrm{PO}$ & $\begin{array}{l}1 \text { If the judge was nominated by } \\
\mathrm{PO}, 0 \text { otherwise }\end{array}$ & 3595 & 0.152 & 0.359 & 0 & 1 \\
\hline SLD & $\begin{array}{l}1 \text { If the judge was nominated by } \\
\text { SLD, } 0 \text { otherwise }\end{array}$ & 3595 & 0.301 & 0.459 & 0 & 1 \\
\hline PiS & $\begin{array}{l}1 \text { If the judge was nominated by } \\
\text { PiS, } 0 \text { otherwise }\end{array}$ & 3595 & 0.230 & 0.421 & 0 & 1 \\
\hline LPR & $\begin{array}{l}1 \text { If the judge was nominated by } \\
\text { LPR, } 0 \text { otherwise }\end{array}$ & 3595 & 0.0459 & 0.209 & 0 & 1 \\
\hline PSL & $\begin{array}{l}\text { If the judge was nominated by } \\
\text { PSL; } 0 \text { otherwise }\end{array}$ & 3595 & 0.0214 & 0.145 & 0 & 1 \\
\hline AWS/UW & $\begin{array}{l}\text { If the judge was nominated by } \\
\text { AWS or UW, } 0 \text { otherwise (due } \\
\text { to the inclusion of the constant } \\
\text { term, this category does not } \\
\text { appear in the regressions, i.e. } \\
\text { serves as a baseline category) }\end{array}$ & 3595 & 0.249 & 0.432 & 0 & 1 \\
\hline Age & $\begin{array}{l}\text { The age of the judge at the time of } \\
\text { appointment }\end{array}$ & 3595 & 57.00 & 7.007 & 36 & 70 \\
\hline Chair & $\begin{array}{l}1 \text { If the judge is a chairman in the } \\
\text { adjudicating bench, } 0 \text { otherwise }\end{array}$ & 3595 & 0.0957 & 0.294 & 0 & 1 \\
\hline Rapporteur & $\begin{array}{l}1 \text { If the judge is a rapporteur in the } \\
\text { adjudicating bench, } 0 \text { otherwise }\end{array}$ & 3595 & 0.135 & 0.342 & 0 & 1 \\
\hline Big bench & $\begin{array}{l}1 \text { If the decision was taken by a } \\
\text { big bench (i.e. minimum } 9 \\
\text { judges), } 0 \text { otherwise }\end{array}$ & 3595 & 0.857 & 0.350 & 0 & 1 \\
\hline Unanimity & $\begin{array}{l}1 \text { If the decision was without } \\
\text { dissenting opinion, } 0 \text { otherwise }\end{array}$ & 3595 & 0.597 & 0.491 & 0 & 1 \\
\hline Fiscal & Cases on fiscal matters & 3595 & 0.178 & 0.383 & 0 & 1 \\
\hline Social & Cases on social matters & 3595 & 0.308 & 0.462 & 0 & 1 \\
\hline Labour & Cases on labor matters & 3595 & 0.00974 & 0.0982 & 0 & 1 \\
\hline
\end{tabular}


Table 1 continued

\begin{tabular}{|c|c|c|c|c|c|c|}
\hline Variables & Description & $\mathrm{N}$ & Mean & $\begin{array}{l}\text { Standard } \\
\text { deviation }\end{array}$ & Min & Max \\
\hline Construction/transport & $\begin{array}{l}\text { Cases on construction and } \\
\text { transportation matters }\end{array}$ & 3595 & 0.0615 & 0.240 & 0 & 1 \\
\hline Financial/business & $\begin{array}{l}\text { Cases on financial or business } \\
\text { matters }\end{array}$ & 3595 & 0.0378 & 0.191 & 0 & 1 \\
\hline Voting law & $\begin{array}{l}\text { Cases on voting, administration, } \\
\text { political parties' matters }\end{array}$ & 3595 & 0.198 & 0.399 & 0 & 1 \\
\hline
\end{tabular}

expected therefore that the vote for constitutionality is less likely when the law is challenged by the party that nominated the judge. In the cases analyzed in this paper, the petitioner, who challenged the law, always claimed its unconstitutionality. Consequently, it is anticipated that the coefficient of Request_align variable should be negative.

\section{A preliminary quantitative exploration}

The preliminary exploration starts by looking at simple conditional probabilities of voting for and against constitutionality. In the first step, the whole 3595 individual votes are divided into those for constitutionality $(56.5 \%)$ and those against constitutionality (43.5\%), in reference to the 344 decisions advanced by the Court. In the second step, it was identified whether the petitioners (i.e. the group of deputies, the President of the Republic or the President of the Sejm) represent the party which nominated a particular judge. Recall that a petitioner challenges the law and claims its unconstitutionality. Overall, Table 2 shows that a vote against constitutionality is slightly more likely when the petitioner and the judge are of the same party $(55.1 \%)$ as compared to the situation where the petitioner is associated with a different party $(39.1 \%)$ using our measure of party alignment. Similarly, the vote for constitutionality is more probable when the petitioner and the judge are from different parties $(60.9 \%)$ than when they are associated with the same parties $(44.9 \%)$.

Table 2 Voting for constitutionality (all decisions)

\begin{tabular}{llcl}
\hline & $\begin{array}{l}\text { Vote against } \\
\text { constitutionality }\end{array}$ & $\begin{array}{l}\text { Vote for } \\
\text { constitutionality }\end{array}$ & Total \\
\hline $\begin{array}{l}\text { A petitioner associated with the same } \\
\text { party as judge }\end{array}$ & $546(55.1 \%)$ & $445(44.9 \%)$ & $991(27.6 \%)$ \\
$\begin{array}{l}\text { A petitioner associated with a different } \\
\text { party }\end{array}$ & $1017(39.1 \%)$ & $1587(60.9 \%)$ & $2604(72.4 \%)$ \\
\begin{tabular}{l} 
Total \\
\hline
\end{tabular} & $1563(43.5 \%)$ & $2032(56.5 \%)$ & $3595(100 \%)$ \\
\hline
\end{tabular}


It is important to stress that the dataset includes the cases filed by Presidents Aleksander Kwaśniewski (left of center) and Bronisław Komorowski (centrist party), who occasionally challenged laws issued by parties from which they politically originated. In that situation, however, judges might be addressing a conflict of interest between two political bodies with the same political preferences. Thus, a vote for constitutionality does not necessary show that the judge goes against her/his ideological background. Similarly, a vote for unconstitutionality does not need to indicate straight ideological alignment. Table 3 introduces conditional probabilities where petitions by Presidents Kwaśniewski and Komorowski are excluded. To a large extent, the results are fairly similar.

Table 4 depicts an additional contingency analysis for nonunanimous decisions (122 decisions). The voting patterns for and against constitutionality seem to be even stronger associated with the background of petitioner. A vote against constitutionality is much more likely when the petitioner and the judge are of the same party $(66.7 \%)$ as compared to the situation where the petitioner is associated with a different party $(38.9 \%)$. Similarly, the vote for constitutionality is more probable when the petitioner and the judge are from different parties $(63.6 \%)$ than when they are associated with the same parties (45.5\%).

Another way of illustrating a potential ideological bias is by showing the votes for and against constitutionality distributed among judges nominated by different political camps when they are faced with cases filed by the SLD (left of center) and PiS (extreme right), i.e. parties considered having the largest ideological disparity. The distribution of votes by judges representing the main political parties (SLDleft of center, PO-center, PiS-extreme right) is shown in Table 5. It can be observed from the table that judges appointed by SLD (left of center) are more likely to vote against constitutionality in cases where the petitioner is associated with SLD. The results are reversed, i.e. SLD judges tend to vote for constitutionality, when the case is filed by PiS (extreme right). Also PiS judges differ in their voting patterns when faced with PiS (more probable vote against constitutionality) and SLD petitioners (more probable vote for constitutionality). PO judges, in turn, are much more likely to vote for constitutionality in cases challenged by both SLD (left of center) and PiS (extreme right). However, a low number of observations for PO judges, when petitioner is associated with SLD, should be acknowledged.

Table 3 Voting for constitutionality (cases filed by Presidents Kwaśniewski and Komorowski are excluded)

\begin{tabular}{llcl}
\hline & $\begin{array}{l}\text { Vote against } \\
\text { constitutionality }\end{array}$ & $\begin{array}{l}\text { Vote for } \\
\text { constitutionality }\end{array}$ & Total \\
\hline $\begin{array}{l}\text { A petitioner associated with the same } \\
\text { party as judge }\end{array}$ & $446(54.5 \%)$ & $373(45.5 \%)$ & $819(25.5 \%)$ \\
$\begin{array}{l}\text { A petitioner associated with a different } \\
\text { party }\end{array}$ & $873(36.4 \%)$ & $1523(63.6 \%)$ & $2396(74.5 \%)$ \\
\begin{tabular}{l} 
Total \\
\hline
\end{tabular} & $1319(41.0 \%)$ & $1896(59.0 \%)$ & $3215(100 \%)$ \\
\hline
\end{tabular}


Table 4 Voting for constitutionality (only nonunanimous decisions)

\begin{tabular}{llll}
\hline & $\begin{array}{l}\text { Vote against } \\
\text { constitutionality }\end{array}$ & $\begin{array}{l}\text { Vote for } \\
\text { constitutionality }\end{array}$ & Total \\
\hline $\begin{array}{l}\text { A petitioner associated with the same } \\
\text { party as judge }\end{array}$ & $294(66.7 \%)$ & $147(33.3 \%)$ & $441(30.4 \%)$ \\
$\begin{array}{l}\text { A petitioner associated with a different } \\
\text { party }\end{array}$ & $392(38.9 \%)$ & $616(61.1 \%)$ & $1008(69.6 \%)$ \\
Total & $686(47.3 \%)$ & $763(52.7 \%)$ & $1449(100 \%)$ \\
\hline
\end{tabular}

Table 5 Vote for constitutionality after identifying petitioners and party nominations (all decisions)

\begin{tabular}{|c|c|c|c|c|}
\hline & \multicolumn{2}{|c|}{ SLD petitioner (left of center) } & \multicolumn{2}{|c|}{ PiS petitioner (extreme right) } \\
\hline & Unconstitutional & Constitutional & Unconstitutional & Constitutional \\
\hline $\begin{array}{l}\text { Judges appointed by SLD (left of } \\
\text { center) }\end{array}$ & $361(56.8 \%)$ & $275(43.2 \%)$ & $83(34.9 \%)$ & $155(65.1 \%)$ \\
\hline Judges appointed by PO (center) & $16(39.0 \%)$ & $25(61.0 \%)$ & $103(26.4 \%)$ & $287(73.6 \%)$ \\
\hline $\begin{array}{l}\text { Judges appointed by PiS } \\
\quad \text { (extreme right) }\end{array}$ & $127(28.1 \%)$ & $325(71.9 \%)$ & $162(52.1 \%)$ & $149(47.9 \%)$ \\
\hline
\end{tabular}

This contingency analysis suggests that, even though a significant number of decisions are unanimous, there is preliminary evidence to support the conjecture that, in general, judges seem to respond (sincerely or strategically) to the identity of the petitioner. Notice, however, that the numbers also indicate that the political response to the petitioners varies somehow across parties. While SLD and PiS judges seem quite sensitive to petitioner being aligned with them or the opposing party, PO judges do not vary significantly in their behavior when exposed to SLD or PiS petitioners. One possible explanation is that PO judges are less polarized because they are politically centrist and more compromising in ideological terms.

\section{Regression analysis}

In order to test more robustly the conjecture that judges vote in accordance with their ideological stance, a more sophisticated regression exercise is employed. A set of logistic regressions is presented to support the above preliminary results, and further investigate determinants of judicial behavior in the Polish TK. A dummy dependent variable, i.e. vote for constitutionality, takes value one when a judge votes for constitutionality and zero otherwise. All independent variables, along the main variable of interest - Request_align, are presented in Table 1.

It is of note that several fixed effects per judge and per court were included in the explanatory variables set as well. Usually with these types of regression, one should consider the signal and not put too much emphasis on the magnitude in the 


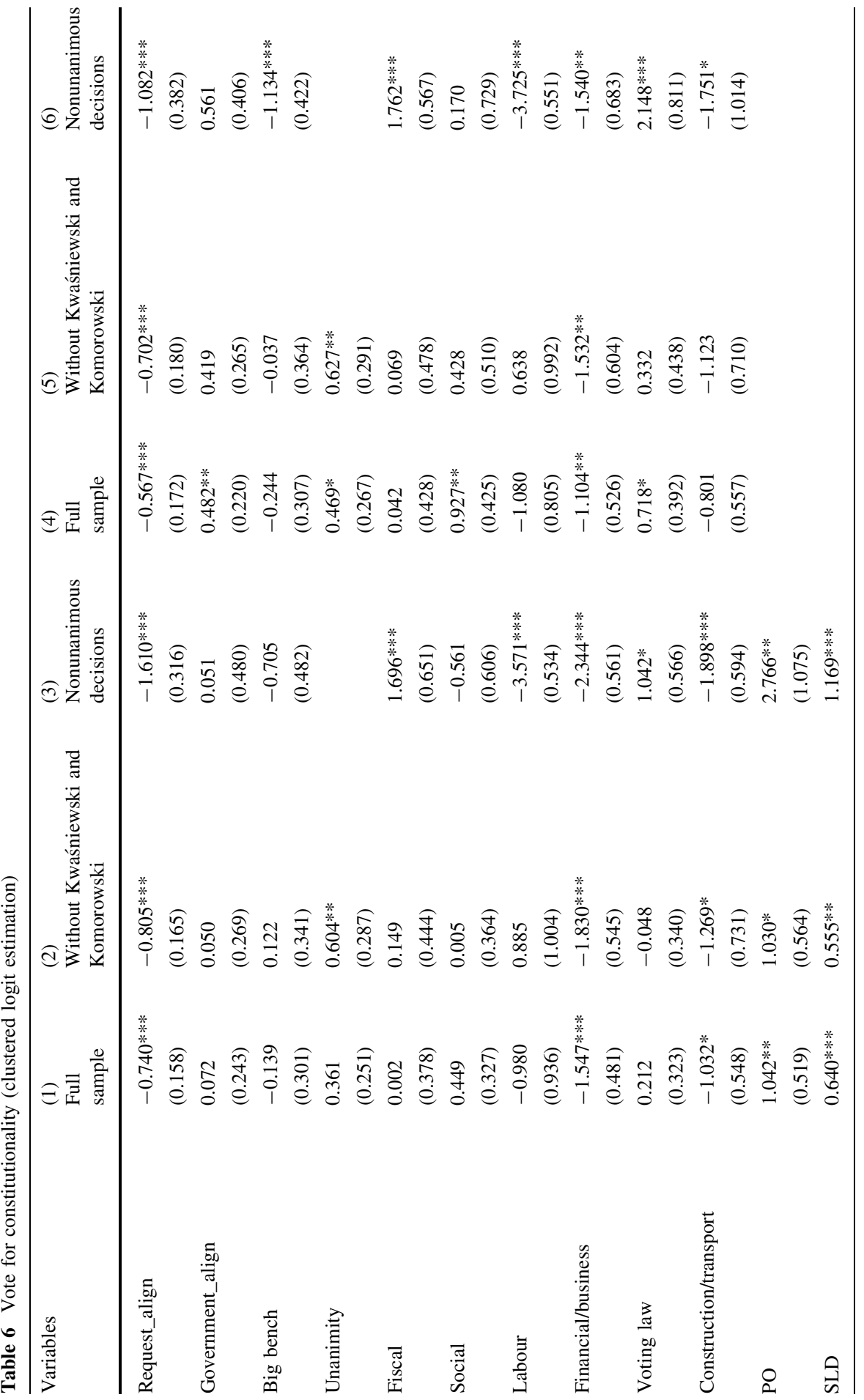




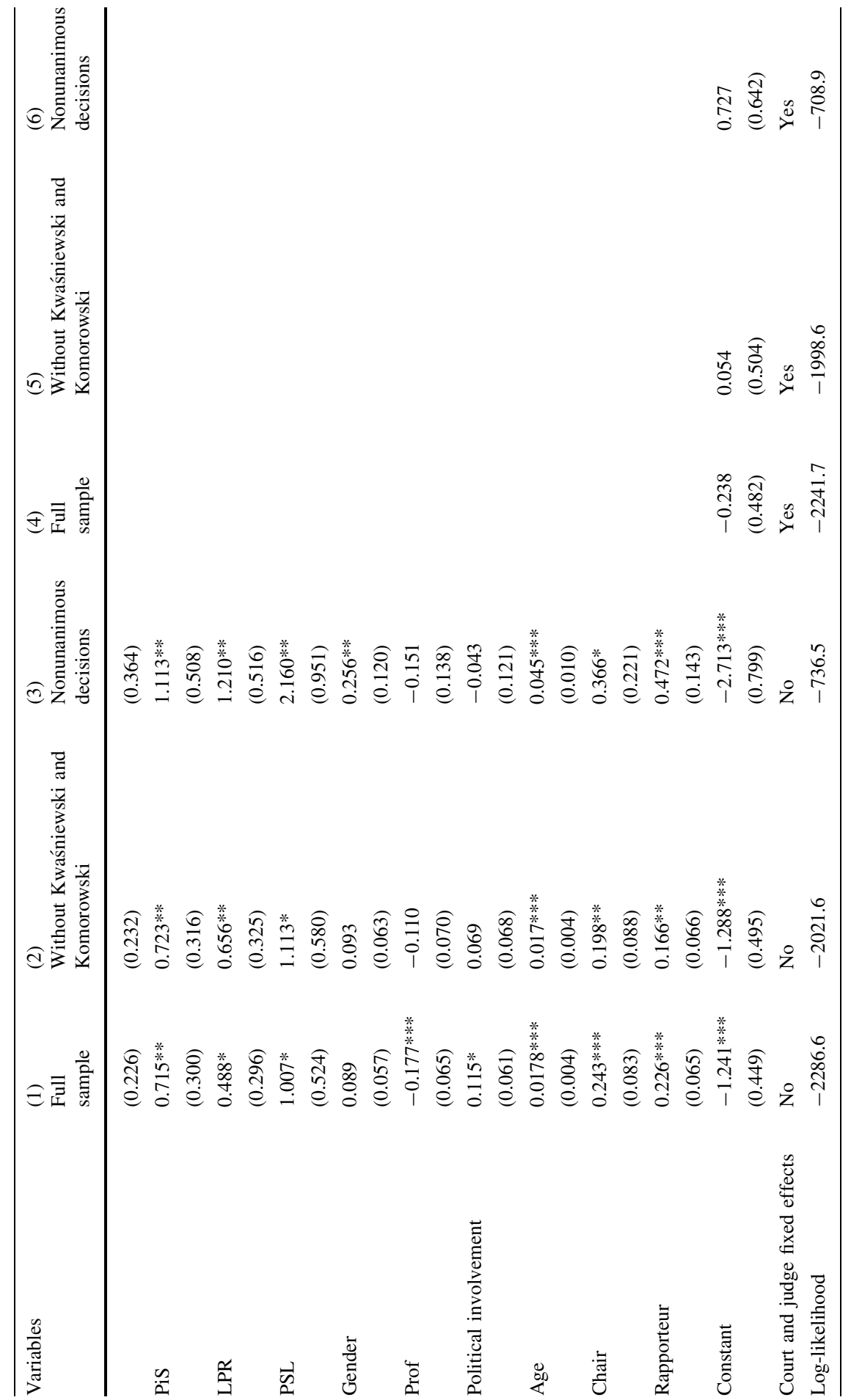




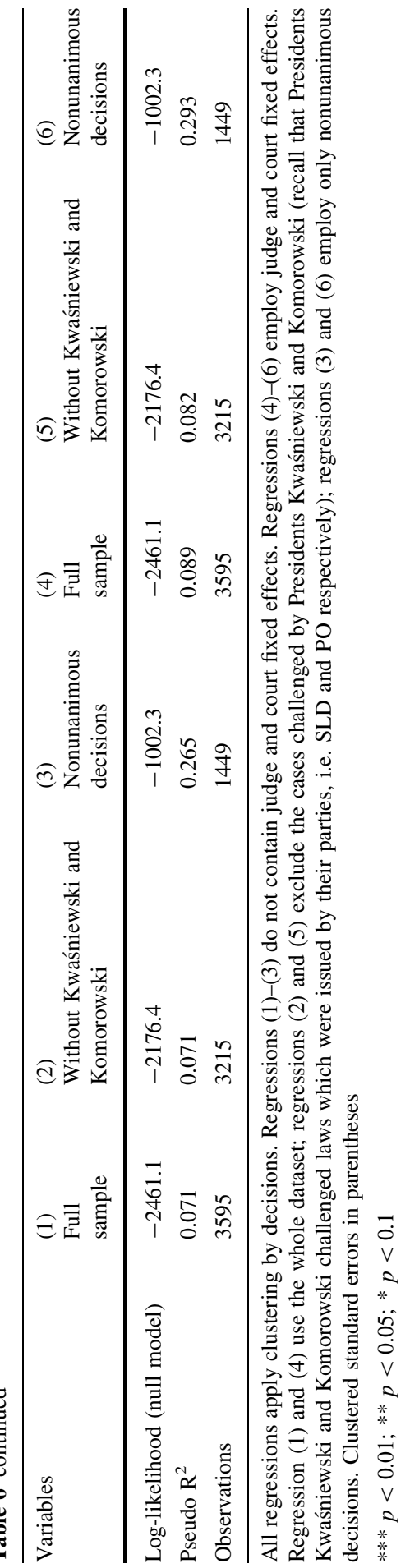


estimated coefficients. Although the purpose is mainly to assess qualitatively the impact of explanatory variables on the probability of a judge voting for constitutionality, the marginal effects for main explanatory variables are also presented. Due to the non-independence of votes within cases and decisions (recall that each case might encompass more than one decision), the appropriate logit models with clustering by case and by decision are applied. Several logit regressions with clustering by decisions are produced in Table 6 .

The regression analysis largely confirms the preliminary analysis of the dataset. The influence of the ideologies and party politics seem to matter. As expected, coefficient for Request_align variable has a negative sign and is robust for any specification. Particularly, the results are robust for selected subsamples dataset and irrespective of clustering by decisions (Table 6) or by cases (available upon request). This strongly supports the view that constitutional judges respond to the interests of political bodies. Overall, the probability that a judge will vote for constitutionality decreases when the judge's party requests the judicial review. Depending on the sample, the marginal effects vary from 18 to $38 \%$. Thus, the probability of voting for constitutionality decreases by $18-38 \%$, if the judge is associated with the party which challenges the law.

In addition, one can observe that a robust pattern of statistical significance is present in case of age and certain party affiliations variables. Some systematic patterns can also be noticed for variables representing specific functions of the judges in the adjudicating bench, i.e. rapporteur or chairman. The same is noticed for the unanimity over the case and specific laws. As to other variables, the vote for constitutionality seems to be random and unexplained by them.

The fact that unanimity significantly increases the likelihood of voting for constitutionality demonstrates that the peer pressure may indeed have some influence on the adjudicating pattern. Institutional constraints may also be reflected through other variables. For instance, the fact that a judge is in charge of drafting the majority opinion (rapporteur) or chairs the adjudicating bench increases the probability of declaring that the law is in conformity with the constitution. Thus, it could be inferred that those judges who hold some functions in the adjudicating benches exert stronger presumption of the constitutionality. Interestingly, the presumption of the constitutionality seems to be stronger also for older judges who, consequently, might be less responsive to parties' interests. For instance, they might not expect further appointment after serving in the Court.

Overall, party affiliation plays an important role in explaining the behavior of the Polish TK judges but with some limitations given the institutional realties in the TK. Therefore, not a simple attitudinal model is proposed but an adjusted model where the advancement of ideological goals coincides with limitations imposed by institutional realities of the TK. The econometric results provide support for this approach.

An alternative way to identify the ideological bias in the court could be by employing interaction terms between the variables concerning which party appointed the judge and whether the petitioner is, for instance, a left wing party. The interpretation is that a judge appointed by a given party and confronted with a 


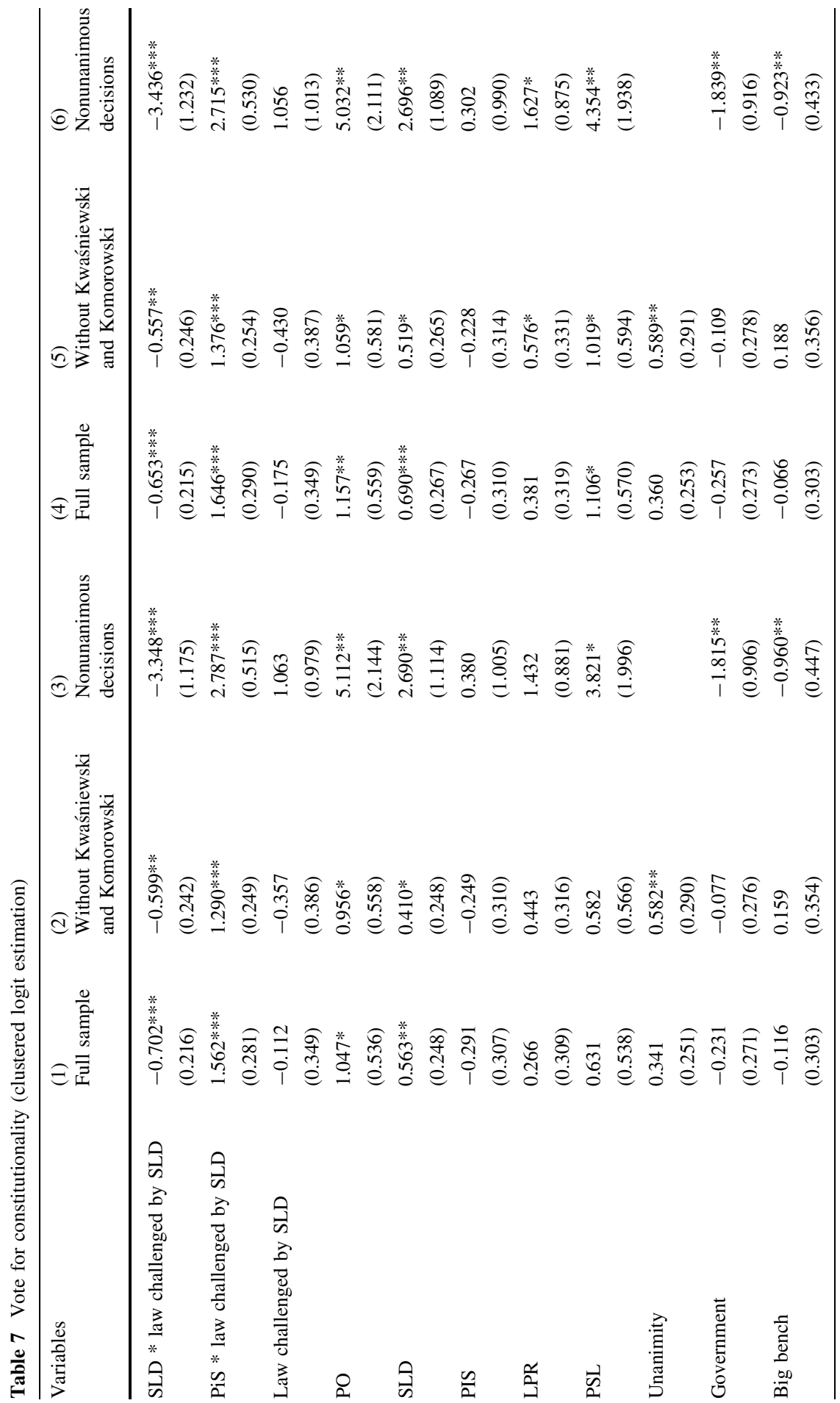




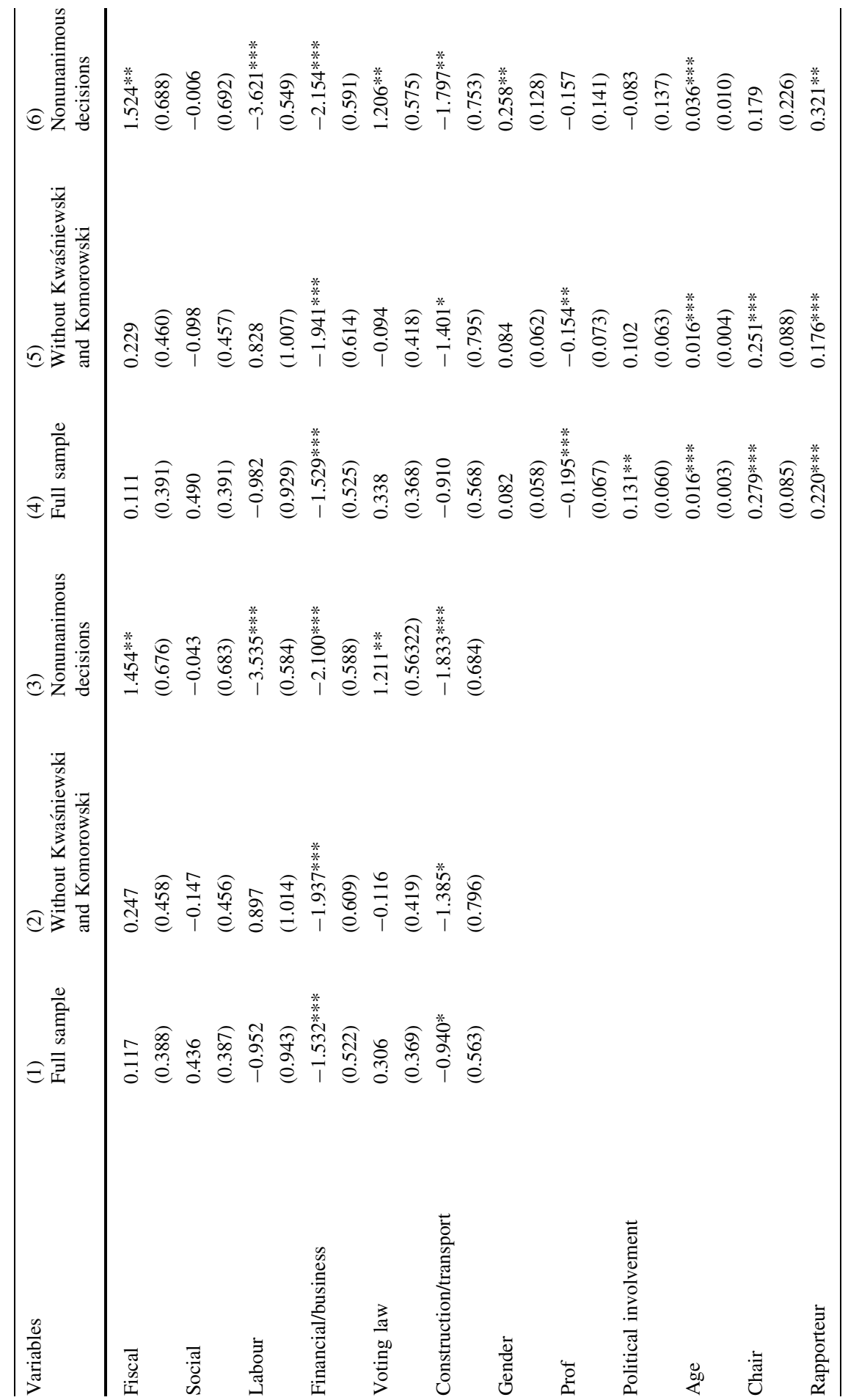




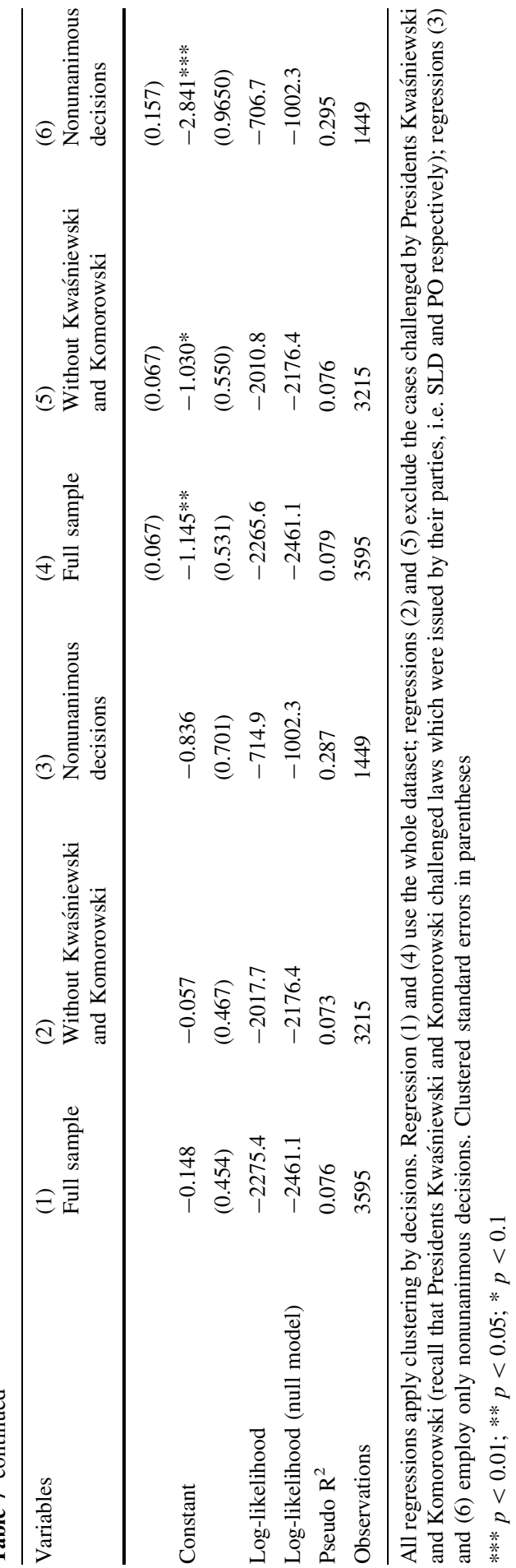


petition filed by the left-wingers is less (if appointed by the left-wing camp) or more (if appointed by the other political camps) likely to vote for constitutionality.

Due to the limited number of observations where PO (center), LPR and PSL judges voted on cases filed by SLD (left of center), the interaction terms for them are dropped. As a result, two interaction terms are considered for two most ideologically polarized parties, i.e. SLD (left of center) and PiS (extreme right). If the hypothesis of ideological alignment holds, then the judge appointed by SLD (left of center) should help SLD petitioners (vote against constitutionality) while the opposite should happen for the judges appointed by PiS (vote for constitutionality). Hence, for the interaction term with appointments by SLD (left of center) one should expect a negative coefficient whereas for appointments by PiS (extreme right), one should anticipate a positive coefficient. Table 7 contains the several logit regressions with clustering by decisions.

As seen from Table 7, the interaction terms of interest are highly statistically significant in all specifications. They have the expected signs, which are in line with the ideological bias and party alignment of the judges. Thus, whenever a judge appointed by SLD (left of center) is confronted with a case filed by SLD, it is less probable that $\mathrm{s} /$ he votes for constitutionality. The marginal effects of interaction "SLD*law challenged by SLD" range between 14 and $63 \%$. That means that a vote for constitutionality drops by $14-63 \%$ when a judge associated with SLD adjudicates in cases filed by SLD (the large marginal effects are observed for regressions on sample of nonunanimous decisions). In contrast, the judges nominated by PiS (extreme right) are more likely to vote for the constitutionality when facing a law challenged by the SLD (left of center). The marginal effects vary between 26 and $48 \%$. That indicates that the vote for constitutionality increases by 26-48 \% when a judge associated with PiS adjudicates in cases petitioned by SLD. The conclusion seems to be that the TK judges cast ideological bias in the direction of the parties which nominated them. This is in particular for judges nominated by the two most polarized political parties.

Similarly to previous regressions, also other variables are statistically robust. Once again institutional constraints seem to play a role. In particular, the fact that the judge is in charge of drafting the Court's judgment (rapporteur) or chairs the adjudicating bench increases the likelihood of voting in favor of constitutionality. Also unanimous decisions are associated (although weakly) with voting in conformity with the constitution, which indicates some peer pressure in the court. Additionally, statistical significance is observed for party affiliation (SLD, left of center), some specific laws, age at the appointment and political involvement of the judges. Other variables do not seem to have a robust pattern of statistical significance.

\section{Conclusion}

The empirical results presented in this paper seem to support some version of the attitudinal and strategic models. It is to say that judicial behavior is influenced by the ideology, either because judges' preferences coincide with the interests of a 
specific party or because the judges are incentivized to show their loyalty to a party. Party alignment exists but subject to some important institutional influences. There is, therefore, little evidence to support the hypothesis of formalist behavior in the Constitutional Court as advocated by traditional legal scholars. These results are in line with previous findings for the constitutional courts, i.e. evidence from France, Italy, Portugal and Spain.

Acknowledgments We are grateful to Jarosław Bełdowski, Matthias Dauner, Nora El-Bialy, Jerg Gutmann, Elena Kantorowicz, Agnes Strauss, Stefan Voigt, Franziska Weber, the editors of this journal, two anonymous referees, the participants of the EDLE seminar held in Bologna on November 6, 2013 and the participants of the 'Empirical Legal Studies at Erasmus School of Law' seminar held at the Erasmus University Rotterdam on November 27, 2013 for useful comments on that paper. The usual disclaimers apply.

\section{References}

Alarie, B., \& Green, A. J. (2008). Should they all just get along? Judicial ideology, collegiality, and appointments to the Supreme Court of Canada. University of New Brunswick Law Journal, 53, 73-91.

Arlota, C., \& Garoupa, N. (2014). Addressing federal conflicts: An empirical analysis of the Brazilian Supreme Court, 1988-2010. Review of Law and Economics, 10, 137-168.

Bojarski, L. (2010). Wybory sedziow do Trybunalu Konstytucyjnego. Instytut Prawa i Spoleczenstwa. http://www.inpris.pl/fileadmin/user_upload/documents/raport_wybory_sedziow_TK.pdf.

Breton, Albert., \& Fraschini, Angela. (2003). The independence of the Italian constitutional court. Constitutional Political Economy, 14, 319-333.

Cameron, C. M., \& Lewis, A. K. (2010). Modeling collegial courts III: Adjudication equilibria. SSRN working-paper. http://ssrn.com/abstract $=1400838$

Carroll, R., \& Tiede, L. (2011). Judicial behavior on the Chilean constitutional court. Journal of Empirical Legal Studies, 8, 856-877.

Chávez, R. B. (2004). The rule of law in nascent democracies: Judicial politics in Argentina. Palo Alto: Stanford University Press.

Edelman, P. H., Klein, D., \& Lindquist, S. A. (2012). Consensus, disorder, and ideology on the Supreme Court. Journal of Empirical Legal Studies, 9, 129-148.

Edwards, H. T., \& Livermore, M. A. (2009). Pitfalls of empirical studies that attempt to understand the factors affecting appellate decisionmaking. Duke Law Journal, 58, 1895-1989.

Eisenberg, T., Fisher, T., \& Rosen-Zvi, I. (2012). Case selection and dissent in courts of last resort: An empirical study of the Israel Supreme Court. In Y.-C. Chang (Ed.), Empirical studies of judicial systems. Academia Sinica: Taipei.

Elster, J. (1993). Constitution-making in Eastern Europe: Rebuilding the boat in the open sea. Public administration, Vol. 71, Spring/Summer.

Epstein, L., \& Knight, J. (1998). The choices justices make. Washington, DC: Congressional Quarterly Inc.

Epstein, L., Landes, W., \& Posner, R. A. (2011). Why (and when) judges dissent: A theoretical and empirical analysis. Journal of Legal Analysis, 3, 101-137.

Escresa, L., \& Nuno, G. (2012). Judicial politics in unstable democracies: The case of the Philippine Supreme Court, 1986-2010. Asian Journal of Law and Economics, 3, (article 2).

Fiorino, N., Gavoille, N., \& Padovano, F. (2015). Rewarding judicial independence: Evidence from the Italian constitutional court. International Review of Law and Economics, 43, 56-66.

Fiorino, N., Padovano, F., \& Sgarra, G. (2007). The determinants of judicial independence: Evidence from the Italian constitutional court (1956-2002). Journal of Institutional and Theoretical Economics, 163, 683-705.

Franck, R. (2009). Judicial independence under a divided polity: A study of the rulings of the French constitutional court, 1959-2006. Journal of Law, Economics and Organization, 25, 262-284. 
Franck, R. (2010). Judicial independence and the validity of controverted elections. American Law and Economics Review, 12, 394-422.

Garcia, A., Sofia, N. G., \& Grembi, V. (2009). Judicial independence and party politics in the Kelsenian constitutional courts: the case of Portugal. Journal of Empirical Legal Studies, 6, 383-404.

Garlicki, L. L. (2002). The experience of the Polish constitutional court. In Wojciech. Sadurski (Ed.), Constitutional Justice, East and West: Democratic legitimacy and constitutional courts in postcommunist Europe in a comparative perspective. The Hague: Kluwer Law International.

Garoupa, N., Gili, M., \& Gómez-Pomar, F. (2011a). An empirical analysis of administrative review by the Spanish Supreme Court. Journal of Empirical Legal Studies, 9, 795-826.

Garoupa, N., \& Ginsburg, T. (2010). Reputation, information, and the organization of the judiciary. Journal of Comparative Law, 4, 226-254.

Garoupa, N., Gómez-Pomar, F., \& Grembi, V. (2013). Judging politically: An empirical analysis of constitutional review voting in the Spanish constitutional court. Journal of Law, Economics and Organization, 29, 513-534.

Garoupa, N., \& Grembi, V. (2015). Judicial review and political partisanship: Consensual vs. majoritarian democracy. International Review of Law and Economics, 43, 32-45.

Garoupa, N., Grembi, V., \& Lin, S. (2011b). Explaining constitutional review in new democracies: The case of Taiwan. Pacific Rim Law and Policy Journal, 20, 1-40.

Ginsburg, T. (2003). Judicial review in new democracies: Constitutional courts in Asian cases. Cambridge: Cambridge University Press.

Ginsburg, T., Elkins, Z., \& Blout, J. (2009). Does the process of constitution-making matter? Annual Review of Law and Social Science, 5, 201-223.

Green, A. J., \& Alarie, B. (2009). Policy preference change and appointments to the Supreme Court of Canada. Osgoode Hall Law Journal, 47, 1-46.

Helmke, G. (2004). Courts under constraints: Judges, Generals, and Presidents in Argentina. Cambridge: Cambridge University Press.

Hilbink, L. (2007). Judges beyond politics in democracy and dictatorship: Lessons from Chile. Cambridge: Cambridge University Press.

Iaryczower, M., Spiller, P. T., \& Tommasi, M. (2002). Judicial independence in unstable environments, Argentina 1935-1998. American Journal of Political Science, 46, 699-716.

Iaryczower, M., Spiller, P. T., \& Tommasi, M. (2006). Judicial lobbying: The politics of labor law constitutional interpretation. American Political Science Review, 100, 1-13.

Kapiszewski, D., \& Taylor, M. M. (2008). Doing courts justice? Studying judicial politics in Latin America. Perspectives in Politics, 64, 741-767.

Kornhauser, L. A. (1992). Modeling collegial courts I: Path-dependence. International Review of Law and Economics, 12, 169-185.

Kornhauser, L. A. (2003). Modeling collegial courts II: Legal doctrine. Journal of Law, Economics and Organization, 8, 441-470.

Landes, W., \& Posner, R. (1975). The independent judiciary in an interest-group perspective. Journal of Law and Economics, 18, 875-901.

Merryman, J. H., \& Pérez-Perdomo, R. (2007). The civil law tradition (3rd Ed.). Palo Alto, CA: Stanford University Press.

Padovano, F. (2009). The time-varying independence of Italian Peak Judicial Institutions. Constitutional Political Economy, 20, 230-250.

Pellegrina, L. D., \& Garoupa, N. (2013). Choosing between the government and the regions: An empirical analysis of the Italian constitutional court decisions. European Journal of Political Research, 52, 431-480.

Posner, R. A. (1993). What do judges and justices maximize? (The same thing everybody else). Supreme Court Economic Review, 3, 1-41.

Posner, R. A. (2005). Judicial behavior and performance: An economic approach. Florida State University Law Review, 32, 1259-1279.

Posner, R. A. (2010). Some realism about judges: A reply to Edwards and Livermore. Duke Law Journal, 59, 1177-1186.

Posner, R. A. (2011). Realism about judges. Northwestern University Law Review, 105, 577-586.

Radzewicz, P. (2010). Wykonywanie orzeczen Trybunalu Konstytucyjnego przez prawodawce. Instytut Prawa i Spoleczenstwa. http://www.inpris.pl/fileadmin/user_upload/documents/raport_wykonywanie_ orzeczen_TK.pdf. 
Ramseyer, J. M., \& Rasmusen, E. B. (2003). Measuring judicial independence: The political economy of judging in Japan. Chicago: University of Chicago Press.

Ramseyer, J. M., \& Rasmusen, E. B. (2006). The case for managed judges: Learning from Japan after the political upheaval of 1993. University of Pennsylvania Law Review, 154, 1879-1930.

Robertson, D. (1998). Judicial discretion in the house of lords. Oxford: Clarendon Press.

Robertson, D. (2010). The judge as political theorist. Princeton: Princeton University Press.

Sadurski, W. (2002). Consitutional justice, east and west: Introduction. In W. Sadurski (Ed.), Constitutional justice, east and west: Democratic legitimacy and constitutional courts in postcommunist Europe in a comparative perspective. The Hague: Kluwer Law International.

Salzberger, E. (1993). A positive analysis of the doctrine of separation of powers, or: Why do we have an independent judiciary? International Review of Law and Economics, 13, 349-379.

Salzberger, E., \& Fenn, P. (1999). Judicial independence: Some evidence from the English court of appeal. Journal of Law and Economics, 42, 831-847.

Schneider, M. R. (2005). Judicial career incentives and court performance: An empirical study of the German Labour Courts of Appeal. European Journal of Law and Economics, 20, 127-144.

Segal, J. A., \& Spaeth, H. J. (2002). The supreme court and the attitudinal model revisited. Cambridge: Cambridge University Press.

Shachar, Y., Gross, M., \& Harris, R. (1997). Anatomy of discourse and dissent in the Supreme CourtQuantitative analyses. Tel Aviv UL Rev, 20, 749-795.

Smyth, R., \& Narayan, P. K. (2004). Hail to the chief! Leadership and structural change in the level of consensus on the High Court of Australia. Journal of Empirical Legal Studies, 1, 399-427.

Songer, D. R., Szmer, J., \& Johnson, S. W. (2011). Explaining dissent on the Supreme Court of Canada. Canadian Journal of Political Science, 44, 389-409.

Spiller, P. T., \& Gely, R. (2007). Strategic judicial decision making. NBER working paper 13321.

Stawecki, T., Staśkiewicz, W., \& Winczorek, J. (2008). Between polycentrism and fragmentation the impact of constitutional Tribunal Rulings on the Polish legal order. Warsaw: Ernst \& Young Polska.

Tate, C. N., \& Sittiwong, P. (1989). Decision making in the Canadian Supreme Court: Extending the personal attributes model across nations. Journal of Politics, 51, 900-916.

Trybunał, K. (2006). Informacja o istotnych problemach wynikajacych z działalności i orzecznictwa Trybunału Konstytucyjnego. Wydawnictwo Trybunału Konstytucyjnego.

Trybunał, K. (2013). Informacja o istotnych problemach wynikajacych z działalności $i$ orzecznictwa Trybunału Konstytucyjnego. Wydawnictwo Trybunału Konstytucyjnego.

Vanberg, G. (2005). The politics of constitutional review in Germany. Cambridge: Cambridge University Press.

Voigt, S., \& Salzberger, E. (2002). Choosing not to choose: When politicians choose to delegate powers. Kyklos, 55, 289-310. 